\title{
S- 9-6 Thiamin Pyrophosphate: Catalytic Mechanism, Role in Protein Turnover
}

\author{
H.Holzer, ${ }^{1}$ and C.GubleR ${ }^{2}$
}

${ }^{1}$ Biochemisches Institut, Universität Freiburg, Hermann-Herder-Str. 7, D-7800 Freiburg, F.R.G. ${ }^{2}$ Department of Chemistry, Brigham Young University, Provo, UT 84602, U.S.A.

\section{DISCOVERY AND CHARACTERIZATION OF THIAMIN PYROPHOSPHATE ACTIVATED ACETALDEHE}

In 1932 Auhagen [1,2] showed that for the decarboxylation of pyruvate to acetaldehyde with yeast extract, as demonstrated earlier by Neuberg and Karczag [3], a heat resistant coenzyme is necessary. In 1937 Lohmann and Schuster [4] isolated the coenzyme, which they called "cocarboxylase" and identified it as the pyrophosphoric acid ester of vitamin B1, i.e. as thiamin pyrophosphate. Different possibilities were discussed for the structure of an "activated acetaldehyde", i.e. acetaldehyde being attached to thiamin pyrophosphate as an intermediate in the pyruvate decarboxylation reaction: pyruvate $\rightarrow$ acetaldehyde $+\mathrm{CO}_{2}$ (for a summary see [5]). In model experiments with thiamin or thiamin analogs Breslow $[6,7]$ presented evidence from considerations of organic chemical reaction mechanisms that acetaldehyde attached to the $\mathrm{C} 2$ of the thiazole ring in thiamin pyrophosphate might be the long seeked for "active acetaldehyde". According to Breslow's proposal acetaldehyde formed from pyruvate on the catalytic center of pyruvate decarboxylase "in status nascenti" is bound to the $\mathrm{C}=\mathrm{N}$ double bond of the thiazole ring corresponding to a "cyan-hydrin" reaction:

$$
\mathrm{HCN}+\mathrm{CH}_{3} \mathrm{CHO} \rightarrow \mathrm{CH}_{3}-\mathrm{CH}-(\mathrm{OH}) \mathrm{CN}
$$

A precursor of the "active acetaldehyde" should be "active pyruvate", i.e. the addition product of pyruvate to thiamin pyrophosphate. Holzer and Beaucamp $[8,9]$, using ${ }^{14} \mathrm{C}$-labeled pyruvate incubated with purified pyruvate decarboxylase from $S$. cerevisiae were the first to isolate and characterize thiamin pyrophosphate containing intermediates of an enzyme catalzyed reaction which showed the structure proposed by Breslow. First evidence for the nature of the radioactive thiamin pyrophosphate containing intermediates came from experiments with $1-{ }^{14} \mathrm{C}$-labeled pyruvate which resulted in the proposed "active pyruvate", i.e. 2- $(\alpha$-hydroxy- $\alpha$-carboxyethyl)TPP, whereas $2-{ }^{14} \mathrm{C}$-labeled pyruvate lead to "active acetaldehyde" i.e. 2 -( $\alpha$-hydroxyethyl)-TPP $[8,9]$. Further characterization of the labeled material was done by using the "sulfite-cleavage" after Williams et al. [10] and by treatment of "active acetaldehyde" with HJ, followed by alkaline hydrolysis which resulted in formation of ${ }^{14} \mathrm{C}$-labeled propionic acid. Additional evidence for the correctness of Breslow's proposal of the structure of active acetaldehyde came from experiments of Krampitz et al. [11,12]. These authors had synthesized 2-( $\alpha$-hydroxyethyl)thiamin and could show that this synthetic material after incubation with ATP and pyrophosphorylating extracts from yeast was able to act as coenzyme of decarboxylation of pyruvate and of the formation of acetoin from acetaldehyde. 


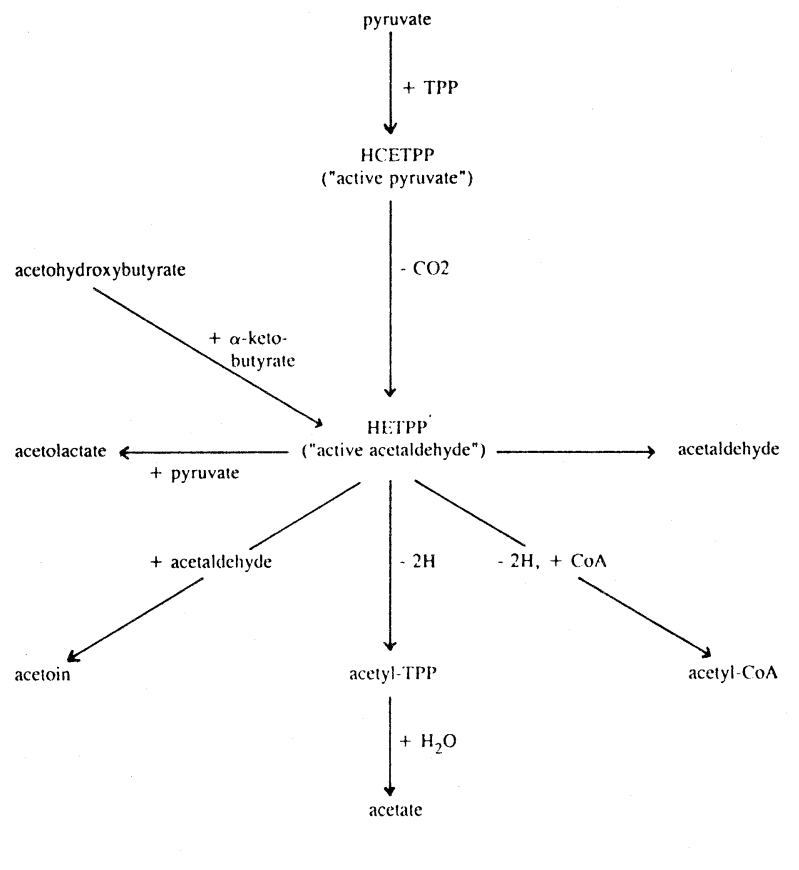

Fig. 1. Enzyme reactions of "active pyruvate" (HCETPP) and "active acetaldehyde" (HETPP).

All enzymatic reactions shown in Fig. 1 starting with "active acetaldehyde" could be demonstrated using as substrate active acetaldehyde prepared from ${ }^{14} \mathrm{C}$-labeled pyruvate and thiamin pyrophosphate with pyruvate dehydrogenase from pig heart muscle $[13,14)]$ and as catalyst the corresponding enzymes (for summaries and details see [5] and [15]).

\section{THIAMIN PYROPHOSPHATE·ACTIVATED GLYCOLALDEHYDE}

"Active glycolaldehyde" i.e. glycolaldehyde attached to thiamin pyrophosphate had been postulated as an intermediate in the transketolase reaction, i.e. the transfer of a C2-piece from one sugar to another [16]. Based on the isolation from enzyme preparations and the structural identification of "active acetaldehyde" (see preceding chapter) it was very probable that "active glycolaldehyde" is a thiamin pyrophosphate activated glycolaldehyde and has the structure 2(1,2-dihydroxyethyl)-thiamin pyrophosphate (DETPP). According to the reaction

$$
\mathrm{CH}_{2} \mathrm{OH}-\mathrm{CO}-\mathrm{COOH}+\mathrm{TPP} \rightarrow \mathrm{DETPP}+\mathrm{CO}_{2}
$$

active glycolaldehyde was prepared with pyruvate dehydrogenase complex from pig heart and hydroxypyruvate and TPP as substrates [17]. The structure of the resulting TPP derivative could be shown to correspond to the proposal by Breslow, i.e. to the formula 2-(1,2-dihydroxyethyl)thiamin pyrophosphate [6]. It could be shown that DETTP is not only the product of decarboxylation of hydroxypyruvate but also a product of incubations of transketolase with TPP and the corresponding sugar-substrates, for example fructose-6-phopshate [17]. In the presence of pyruvate dehydrogenase complex from pig heart, NAD and CoA the isolated radioactive DETPP is oxidized to glycolic acid. Glycolyl-CoA is an intermediate [17]. 


\section{MECHANISMS OF TRANSKETOLASE (E.C. 2.2.1.1) REACTIONS}

Transketolase (TK) plays an integral and rate-limiting role in the operation of the hexose monophosphate shunt pathway for the metabolism of glucose-6-phosphate. The key reaction is the transfer of an activated $\mathrm{C}_{2}$-fragment (activated glycolaldehyde, or 2-(1,2-dihydroxyethyl)-thiamin pyrophosphate, DETPP) from an appropriate ketosugar donor to an acceptable aldosugar acceptor [18-20]. In this thiamin pyrophosphate-catalyzed transfer, the leaving group is an aldose moiety with two fewer $\mathrm{C}$-atoms instead of $\mathrm{CO}_{2}$ as in the case with pyruvate decarboxylase and pyruvate dehydrogenase.

Active ketol donors must have the $\mathrm{OH}$ groups on $\mathrm{C}_{3}$ and $\mathrm{C}_{4}$ trans to each other with the $\mathrm{C}_{3^{-}}$ $\mathrm{OH}$ in the L-configuration and the $\mathrm{C}_{4}-\mathrm{OH}$ in the D. Thus D-Xu-5-P, D-fructose-6-P and Dsedoheptulose-7-P are the most active donors. However L-erythrulose, D-xylulose, hydroxypyruvate and D-glycero-D-idooctulose have also been found to act as donors under certain circumstances [18-20]. As accpetors, D-GA-3-P, D-erythrose-4-P and D-R-5-P are the most efficient, but D-G-6-P, D-allose-6-P, D-arabinose-5-P, glycolaldehyde, D-glyceraldehyde and formaldehyde may also act in certain systems.

\section{THIAMIN PYROPHOSPHATE ACTIVATED FORMALDEHYDE}

Incubation of pyruvate dehydrogenase complex from pig heart with thiamin pyrophosphate and glyoxylate results in the formation of 2-hydroxymethyl-thiamin pyrophosphate, i.e. thiamin pyrophosphate-activated formaldehyde [21]:

$$
\mathrm{CHO}-\mathrm{COOH}+\mathrm{TPP} \rightarrow \mathrm{HOCH}_{2}-\mathrm{TPP}+\mathrm{CO}_{2}
$$

With the methods used for structural identification of active acetaldehyde, active pyruvate and active glycolaldehyde, it was shown that the structure of the active formaldehyde corresponds to the proposal of Breslow [5,6]. Krakow et al. [22,23] have isolated and characterized an enzyme from Escherichia coli which catalyzes the condensation of 2 moles of glyoxylate to give $1 \mathrm{~mol}$ of tartronic semialdehyde plus $1 \mathrm{~mol}$ of $\mathrm{CO}_{2}$ :

$$
2-\mathrm{CHO}-\mathrm{COOH} \rightarrow \mathrm{CHO}-\mathrm{CHOH}-\mathrm{COOH}+\mathrm{CO}_{2}
$$

The dependence on thiamin pyrophosphate of this condensation reaction suggested that thiamin pyrophosphate activated formaldehyde is an intermediate in the reaction. With the active formaldehyde prepared from glyoxylate and pyruvate dehydrogenase complex (see above) it could be shown that the thiamin pyrophosphate activated formaldehyde is indeed an intermediate in the "glyoxylic acid carboligase" reaction [21,24].

\section{CONTROL OF PROTEIN TURNOVER BY THIAMIN PYROPHOSPHATE}

Addition of ammonia to glucose-oxidizing yeast cells leads to an increase in the content of pyruvate decarboxylase [25]. The increase of pyruvate decarboxylase activity is prevented by addition of actinomycin or other inhibitors of protein synthesis [25,26]. The addition of thiamin causes similarly to ammonia an increase in the synthesis of pyruvate decarboxylase. The pyruvate decarboxylase-inducing activity of thiamin is clearly shown in experiments with the thiamindeficient mutant of $S$. cerevisiae [25]. The most probable explanation for the action of thiamin on the level of pyruvate decarboxylase is that either thiamin is an inducer of the synthesis of this enzyme or that thiamin pyrophosphate stabilizes the enzyme before proteolytic degradation, i.e. 
inhibits proteolytic degradation. Such a stabilizing effect is well known for other coenzymes [27]: pyridoxal phosphate [28,30,31], NAD [29,30], FAD [32].

\section{REFERENCES}

[ 1] Auhagen, E. (1932): Co-Carboxylase, ein neues Co-Enzym der alkoholischen Gärung. Hoppe-Seyler's Z. Physiol. Chem., 204, 149-167.

[ 2] Auhagen, E. (1932): Über Co-Carboxylase. Hoppe-Seyler's Z. Physiol. Chem., 209, 20-26.

[ 3] Neuberg, C., and Karczag, L. (1911): Über zuckerfreie Hefegärung. Biochem. Z., 37, 170-176.

[ 4] Lohmann, K., and Schuster, Ph. (1937): Untersuchungen über die Cocarboxylase. Biochem. Z., 294, 188.

[ 5] Holzer, H. (1961): Wirkungsmechanismus von Thiaminpyrophosphat. Angew. Chem., 73, 721-727

[6] Breslow, R. (1957): Rapid deuterium exchange in thiazolium salts. J. Amer. Chem. Soc., 79, 1762-1763.

[ 7] Breslow, R. (1958): On the mechanisms of thiamin action. IV. Evidence from studies on model systems. J. Amer. Chem. Soc., 80, 3719-3726.

[ 8] Holzer, H., and Beaucamp, K. (1959): Nachweis und Charakterisierung von Zwischenprodukten der Decarboxylierung und Oxydation von Pyruvat: "aktiviertes Pyruvat" und "aktiviertes Acetaldehyd". Angew. Chem., 71, 776.

[9] Holzer, H. and Beaucamp, K. (1961): Nachweis und Charakterisierung von $\alpha$-LactylThiaminpyrophosphat ("Aktiviertes Pyruvat") und $\alpha$-Hydroxyäthyl-Thiaminpyrophosphat ("Aktiviertes Acetaldehyd") als Zwischenprodukt der Decarboxylierung von Pyruvat mit Pyruvatdecarboxylase aus Bierhefe. Biochim. Biophys. Acta, 46, 225-243.

[10] Williams, R.R., Waterman, R.E., Keresztesy, J.C., and Buchman, E.R. (1935): Studies of crystalline vitamin $B_{1}$. III. Cleavage of vitamin $B_{1}$ with sulfite. J. Amer. Chem. Soc., 57, 536.

[11] Krampitz, L.O., Greull, G., Miller, C.S., Bicking, J.B., Skeggs, H.R., and Sprague, J.M. (1958): An active acetaldehyde-thiamine intermediate. J. Amer. Chem. Soc., 80, 5893-5894.

[12] Krampitz, L.O., Greull, G., and Suzuki, I. (1959): An active acetaldehyde-thiamin intermediate. Fed. Proc., 18, 266.

[13] Scriba, P., and Holzer, H. (1961): Gewinnung von $\alpha$-Hydroxyäthyl-2-thiaminpyrophosphat aus Schweineherzmuskel. Biochem. Z., 334, 473-486.

[14] Ullrich, J., and Holzer, H. (1963): pH-Abhängigkeit der HETPP-Ausbeute beim Umsatz von Pyruvat mit TPP an Pyruvatoxidase aus Schweineherzmuskel. Biochem. Z., 337, 345-348.

[15] Holzer, H., da Fonseca-Wollheim, F., Kohlhaw, C., and Woenckhaus, Ch.W. (1962): Active forms of acetaldehyde, pyruvate and glycolic aldehyde. Ann. New York Acad. Sci., 98, 453-465.

[16] Datta, A.G., and Racker, E. (1959): Participation of an active glycolaldehyde-enzyme in the transketolase-catalyzed reaction. Arch. Biochem. Biophys., 82, 489-491.

[17] Pohlandt, F., Kohlhaw, G., and Holzer, H. (1967): Enzymatische und nicht-enzymatische Darstellung von "Thiaminpyrophosphat-aktiviertem Glykolaldehyd". Z. Naturforsch., 22b, 407-412.

[18] Datta, A.G., and Racker, E. (1961): Mechanism of action of transketolase. J. Biol. Chem., 236, 617-623. 
[19] Racker, E. (1961): Transketolase, in The Enzymes, ed. by Boyer, P.D., Lardy, H., and Myrback, K., Academic Press, New York, Vol. 5, 2nd Ed. Ch. 24A.

[20] Horecker, B.L. (1964). Transketolase and Transaldolase, in Comprehensive Biochemistry, ed. by Florkin, M., and E.H. Stoz, E.H., Elsevier, New York, pp. 48-70.

[21] Kohlhaw, G., Deus, B., and Holzer, H. (1965): Enzymatic preparation, structure, and properties of thiamine pyrophosphate-activated formaldehyde. J. Biol. Chem., 240, 2135-2141.

[22] Krakow, G., and Barkulis, S.S. (1956): Conversion of glyoxylate to hydroxypyruvate by extracts of Escherichia coli. Biochim. Biophys. Acta, 21, 593.

[23] Krakow, G., Barkulis, S.S., and Hayashi, J.A. (1961): Glyoxylic acid carboligase: An enzyme present in glycolate-grown Escherichia coli. J. Bacteriol., 81, 509-518.

[24] Jaenicke, L., and Koch, J. (1962): Zum Mechanismus der Carboligasereaktion. Hydroxymethyl-thiaminpyrophosphat, ein neues aktives Kohlenstoffragment. Biochem. Z. 336, 432-443.

[25] Holzer, H., and Witt, I. (1964): The role of pyruvate decarboxylase in the regulation of fermentation in yeast. Sixth Int. Congr. Biochem., New York, Abstracts Vol. IX33, p. 721.

[26] Witt, I.. and Heilmeyer, L. (1966): Regulation of pyruvate decarboxylase (E.C.4.1.1.1) synthesis by coenzyme induction in Saccharomyces cerevisiae. Biochem. Biophys. Res. Commun., 25, 340-345.

[27] Jaenicke, R. (1987): Folding and association of proteins. Progr. Biophys. Mol. Biol. 49, 117-237.

[28] Katunuma, N., Kominami, E., and Kominami, S. (1971): A new enzyme that specifically inactivates apo-protein of pyridoxal enzymes. Biochem. Biophys. Res. Commun. 45, 70-75.

[29] Katunuma, N., Kominami, E., and Kominami, S. (1971): A new enzyme that specifically inactivates apo-protein of NAD-dependent dehydrogenases. Biochem. Biophys. Res. Commun., 45, 76-81.

[30] Katunuma, N. (1977): New intracellular proteases and their role in intracellular enzyme degradation. Trends Biochem. Sci., 2, 122-125.

[31] Schött, E.H., and Holzer, H. (1974): Purification and some properties of tryptophan synthase inactivase II from yeast. Eur. J. Biochem., 42, 61-66.

[32] Brandsch, R., Bichler, V., and Krauss, B. (1989): Binding of FAD to 6-hydroxy-Dnicotine oxidase apoenzyme prevents degradation of the holoenzyme. Biochem. J., 258, 187-192. 